\title{
Clinical and biological predictors of Alzheimer's disease in patients with amnestic mild cognitive impairment
}

\section{Preditores clínicos e biológicos da evolução para doença de Alzheimer em pacientes com comprometimento cognitivo leve amnéstico}

\author{
Orestes V. Forlenza, ${ }^{1}$ Breno S. Diniz, ${ }^{1}$ Leda L. Talib, ${ }^{1}$ Marcia Radanovic, ${ }^{1}$ Monica S. Yassuda, ${ }^{1,2}$ Elida B. Ojopi, ${ }^{1}$ \\ Wagner F. Gattaz ${ }^{1}$ \\ 1 Psychogeriatric Clinic and Laboratory of Neuroscience (LIM-27), Department and Institute of Psychiatry, School of Medicine, Universidade \\ de São Paulo (USP), São Paulo, SP, Brazil \\ 2 Gerontology, School of Arts, Sciences and Humanities (EACH), Universidade de São Paulo (USP), São Paulo, SP, Brazil
}

\begin{abstract}
Objective: To identify predictors of the progression from pre-dementia stages of cognitive impairment in Alzheimer's disease is relevant to clinical management and to substantiate the decision of prescribing antidementia drugs. Method: Longitudinal study of a cohort of elderly adults with amnestic mild cognitive impairment and healthy controls, carried out to estimate the risk and characterize predictors of the progression to Alzheimer's disease. Results: Patients with amnestic mild cognitive impairment had a higher risk to develop Alzheimer's disease during followup (odds ratio $=4.5, \mathrm{CI}_{95 \%}[1.3-13.6], \mathrm{p}=0.010$ ). At baseline, older age, lower scores on memory tests and presence of the APOE* 4 allele predicted the progression from amnestic mild cognitive impairment to Alzheimer's disease. In a sub sample of amnestic mild cognitive impairment patients, those who progressed to Alzheimer's disease had lower cerebrospinal fluid concentrations of amyloid-beta peptide $\left(A \beta_{42}, p=0.020\right)$ and higher concentrations of total TAU $(\mathrm{p}=0.030)$ and phosphorylated TAU ( $p=0.010$ ), as compared to non-converters. Discussion: This is the first Brazilian study to report cerebrospinal fluid biomarkers in the prediction of the conversion from MCI to Alzheimer's disease. Our data are in accordance with those reported in other settings. The measurement of cerebrospinal fluid total-TAU, phospho-TAU and A $\beta_{42}$ may help identify patients with mild cognitive impairment at higher risk for developing Alzheimer's disease.
\end{abstract}

Descriptors: Alzheimer's disease; Cognition disorders; Critical pathways; Biological indicators; Neurobehavioral manifestations

\section{Resumo}

Objetivo: A identificação de preditores da conversão para a doença de Alzheimer em pacientes com comprometimento cognitivo leve é relevante para o manejo clínico e para decidir sobre a prescrição de drogas antidemência. Método: Estudo longitudinal em coorte de individuos idosos com comprometimento cognitivo leve amnéstico e controles saudáveis; estimativa do risco da progressão para doença de Alzheimer nos dois grupos; determinação das variáveis preditivas desse desfecho. Resultados: Pacientes com comprometimento cognitivo leve amnéstico apresentaram maior risco de desenvolver doença de Alzheimer ao longo do seguimento (odds ratio $=4,5$, $\left.C_{95 \%}[1,3-13,6], p=0,012\right)$. Na avaliação inicial, idade mais avançada, escores mais baixos nos testes cognitivos e do alelo APOE* 4 foram preditores da conversão do comprometimento cognitivo leve amnéstico para doença de Alzheimer. Em uma subamostra de pacientes com comprometimento cognitivo leve amnéstico, aqueles que progrediram para doença de Alzheimer tinham concentraçôes liquóricas mais baixas do peptideo beta-amilóide $\left(A \beta_{42}, p=0,020\right)$ e mais altas da proteina TAU total $(p=0,030)$ e TAU fosforilada $(p=0,010)$ do que os pacientes que não progrediram para doença de Alzheimer. Discussão: Este éo primeiro estudo brasileiro com biomarcadores liquóricos a relatar preditores da conversão comprometimento cognitivo levedoença de Alzheimer. Nossos dados biológicos (aumento de TAU total e fosfoTAU; redução de $A \beta_{42}$ ), e podem auxiliar na identificação dos pacientes com comprometimento cognitivo leve com maior risco de evolução para demência.

Descritores: Doença de Alzheimer; Transtornos cognitivos; Procedimentos clinicos; Indicadores biológicos; Manisfestaçôes neurocomportamentais
Submitted: May 27, 2009

Accepted: August 13, 2009
Correspondence

Orestes V. Forlenza

Laboratório de Neurociências (LIM 27), Departamento e Instituto de Psiquiatria

Hospital das Clínicas da Faculdade de Medicina da Universidade de São Paulo

Rua Dr. Ovídio Pires de Campos 785 - 3aandar

05403-010 São Paulo, SP, Brazil

Phone: (+55 11) 3069-7924 Fax: (+55 11) 3085-5412

E-mail: forlenza@usp.br 


\section{Introduction}

The term mild cognitive impairment (MCI) has been extensively used in clinical and research settings to describe subjects with objective cognitive impairment in one or more cognitive domains, with no evidence of clinically relevant functional impairment and dementia. ${ }^{1}$ Patients with MCI have an increased risk for developing dementia, particularly Alzheimer's disease (AD), as compared to older adults without evidence of cognitive impairment, with annual progression rates ranging from 5 to $40 \%$ per year. ${ }^{2}$ Recent epidemiological studies have addressed the characteristics of pre-dementia states in Brazil. Hototian et al. reported a prevalence of $16 \%$ of cognitive impairment no dementia (CIND) in subjects over 60 years-old in Sao Paulo. ${ }^{3}$ Chaves et al. reported that the incidence of mild cognitive impairment, as defined by the Clinical Dementia Rating of 0.5 , was 13.2 per 1000 elderly subjects per year. ${ }^{4}$ In a clinical setting, we have recently shown that patients with multiple-domain amnestic MCI tend to be older and to have a worse cognitive performance than those with single-domain MCI (amnestic and non-amnestic), suggesting that the former subgroup may represent a more severe stage of MCI.,

The cross-sectional diagnosis of MCI still yields a heterogeneous group of patients, including subjects with varying degree of cognitive impairment. ${ }^{7}$ A significant proportion of subjects diagnosed as such may resume normal cognitive performance upon follow-up. ${ }^{8}$ Alternatively, other cognitive outcomes including non-AD dementia are also possible. ${ }^{9}$

The characterization of clinical and biological predictors of conversion (MCI-AD) is clinically relevant, since it may help identify subjects at higher risk of $\mathrm{AD}$, who are most likely to benefit from the early intervention with antidementia drugs. ${ }^{10}$ This perspective is even more relevant in the light of the development of drugs with disease-modifying properties. ${ }^{11}$ Most clinical and epidemiological studies have shown that advanced age, worse baseline cognitive performance and functional deficits are the important clinical predictors of progression to $\mathrm{AD}$ in $\mathrm{MCI}$ patients. ${ }^{12,13}$ Important biological predictors are the presence of the $\mathrm{APOE}^{*} 4$ allele; ${ }^{14}$ low amyloid- $\beta_{42}$ and elevated Tau and phospho-Tau protein in the CSF, ${ }^{15}$ whole-brain and hippocampal atrophy, the rate of brain atrophy in structural $\mathrm{MRI}^{16,17}$ and temporo-parietal hypometabolism/low blood flow in FDG-PET and SPECT. ${ }^{18,19}$ To the best of our knowledge, no study have so far addressed the contribution of clinical and biological predictors of the risk of progression from amnestic MCI to AD in the Brazilian elderly population. Therefore, the aim of the present study is to determine the annual rate of progression from amnestic MCI to $\mathrm{AD}$ in a clinical cohort of elderly subjects and the clinical and biological predictors of progression to $\mathrm{AD}$.

\section{Method}

Detailed information on recruitment, clinical and neuropsychological evaluations, and diagnostic criteria can be found in a previous publication in this Journal, in which we addressed the cross-sectional characteristics of this cohort. ${ }^{6}$ Signed informed consents were obtained from all participants prior to enrolment. This study was approved by local Ethics Committee (process number 1053/02) and was performed according to the Helsinki Declaration.

\section{Patients}

Two hundred and fifty-eight outpatients (75\% female) were assessed at the Institute of Psychiatry, University of Sao Paulo, Brazil, between December 2001 and March 2009 (mean age: $70.6 \pm 6.8$ years; mean education: $9.8 \pm 5.7$ years). At baseline assessment, 73 subjects were diagnosed with $\mathrm{AD}, 97$ had amnestic MCI (20 with single-domain amnestic MCI and 77 multipledomain amnestic MCI), and 88 were cognitively unimpaired (controls).

\section{Clinical and neuropsychological assessment}

All subjects were examined by an expert multidisciplinary team, including geriatric psychiatrists, neurologists, geriatricians and neuropsychologists. Mental state examination was performed with the Brazilian version of the Cambridge Examination for Mental Disorders of the Elderly (CAMDEX) semi-structured interview, ${ }^{20,21}$ which yields scores for its cognitive subscale CAMCOG, the Mini-Mental State Examination (MMSE) and the Hachinski Ischemic Score. The Clock Drawing Test, which is part of the CAMCOG schedule, was additionally scored according to Sunderland's guidelines. The 21-item Hamilton Depression Scale (HAM-D) 22 was administered to rule out depressive symptomatology. Scores bellow 7 were considered as evidence of absence of current depressive episodes. Patients with evidence of depressive episodes were referred to psychiatric treatment and did not undergo cognitive neuropsychological assessments.

Trained neuropsychologists administered neuropsychological examinations to all study participants. The neuropsychological battery included tests for episodic memory: the Rivermead Behavioural Memory Test (RBMT) ${ }^{23}$ and the Fuld ObjectMemory Evaluation (FOME) ${ }^{24}$ the Brazilian version of the Short Cognitive Test (SKT), ${ }^{25}$ verbal fluency (category: fruit); Trail Making Test A (TMT A), and Trail Making Test B (TMT B).

Evidence of functional decline was based on the scores of the Informant Questionnaire on Cognitive Decline in the Elderly (IQCODE $)^{26}$ and on all available evidence of difficulties to perform basic and instrumental activities of daily living, reported by a close relative or caregiver, and on the patient's self-report.

Follow-up assessments were done in one-year intervals for all patients and controls in which the same clinical and neuropsychological protocols were administered.

\section{Diagnosis}

Consensus diagnoses were reached in multidisciplinary expert meetings, taking into account clinical, neuropsychological, laboratorial, and neuroimaging data. $\mathrm{AD}$ was diagnosed according to the NINCDS-ADRDA criteria. ${ }^{27}$ The amnestic MCI diagnosis was made according to the following criteria: 1) subjective memory complain, preferably corroborated by an informant; 2) 
objective memory impairment when performing cognitive tests of the assessment battery that was not severe enough to reach dementia diagnosis; 3) preserved global intellectual function; 4) preserved or minimal impairments in activities of daily living; 5) not demented. ${ }^{1,28}$ Evidence of objective memory impairment was defined as performance bellow 1.5 standard deviation in the memory tests (RBMT and/or FOME), adjusted for age and educational status. ${ }^{29}$ Subjects without evidence of cognitive impairment were included in the control group.

\section{APOE*4 genotyping}

Genomic DNA was isolated from whole blood from each subject and the $A P O E$ genotyping was performed using the $\operatorname{TaqMan}^{\circledR}{ }^{\circledR}$ '-exonuclease allelic discrimination assay ${ }^{30}$ obtained from Applied Biosystems (Foster City, CA, USA) with primers and probes sets from inventoried assays. This methodology uses two PCR assays to screen for single nucleotide polymorphisms (rs429358, rs7412) within the exon 4 of APOE gene. Results from the individual assays were used to determine the ultimate $A P O E$ genotype.

\section{Cerebrospinal fluid (CSF) collection}

A sub sample of 45 aMCI patients consented to undergo lumbar puncture for CSF sampling and biomarker analysis. CSF samples were taken by lumbar puncture in the L3/L4 or L4/L5 intervertebral space, with a 23-gauge needle and using polypropylene tubes, in the morning. A total of $12-15 \mathrm{~mL}$ of CSF was collected and, then, centrifuged at $3200 \mathrm{~g}$ for 10 minutes at $4^{\circ} \mathrm{C}$. After centrifugation, the samples were separated in $0.5 \mathrm{~mL}$ aliquots, and immediately frozen at $-80^{\circ} \mathrm{C}$ until analysis without being thawed and re-frozen.

\section{CSF biomarkers analysis}

The CSF biomarkers T-Tau, P-Tau ${ }_{181}$ and $A \beta_{1-42}$ analyses were done in duplicate with the INNo-Bia AlzBio3 assay (Innogenetics, Ghent, Belgium), a multiplex microsphere-based Luminex xMAP platform that allows simultaneous analysis of these biomarkers. After pre-wetting of the filter plate with a wash buffer, a suspension of microsphere carrying the corresponding capturing antibodies (AT120, AT270 and 4D7A3 for t-Tau, P-Tau and $A \beta_{1-42}$ respectively) was added to the plate. A mixture of biotinylated detection monoclonal antibodies, designed to detect specifically one of the capturing antibodies (HT7 for t-Tau and P-Tau and 3D6 for $A \beta_{1-42}$ ), and $75 \mu \mathrm{L}$ of CSF or standards were added to the plate and incubated overnight in the dark. Next, the plate was washed and a detection conjugate (phycoerythrin-labeled streptavidin) was added and incubated for $1 \mathrm{~h}$ at room temperature. The plate was washed and after the addition of a reading solution (phosphate buffer saline) the assay was analyzed on a Luminex 100 IS platform (Luminex, Austin, Texas, US). Standard curves were constructed for each biomarker using a sigmoidal curve fitting method, and the mean fluorescence values for the duplicate CSF samples were used to determine the concentration of T-Tau, P-Tau and $A \beta_{1-42}$.

\section{Statistical analysis}

We performed Pearson's Chi-square test to assess differences in the distribution of gender and $\mathrm{APOE}^{*} 4$ frequency among different diagnostic groups. Kolmogorov-Smirnov tests were done to assess the normality of the distribution for each continuous variable. As these analyses showed that all variables had normal or near-normal distribution, we carried out parametric statistical tests for all analyses. Univariate analysis of variance (ANOVA) was performed to assess mean differences for socio-demographic data, clinical variables, and scores on cognitive and neuropsychological tests among the diagnostic groups. If differences on socio-demographic or clinical variables known to influence cognitive performance were statistically significant among diagnostic groups in univariate analysis, we carried out multivariate analyses to control for the influence of these potential confounding variables on the scores of cognitive and neuropsychological tests. In addition, we carried out Bonferroni analyses for multiple comparisons to address mean differences in the scores of cognitive and neuropsychological tests between each diagnostic group.

T-tests were done to ascertain mean differences in sociodemographic, clinical scores on cognitive and neuropsychological tests and Pearson's Chi-square analysis to assess for differences in the distribution of gender and $\mathrm{APOE}^{*} 4$ frequency between converters and non-converters to $\mathrm{AD}$ in the control and $\mathrm{MCI}$ groups. Kaplan-Meyer survival analysis with log-rank tests were done to ascertain differences in the survival time prior to conversion in the MCI and control groups. Cox regression analysis, with backward likelihood ratio entry model, was performed to assess which variables were the most important predictors of conversion to $\mathrm{AD}$. The probability for stepwise entry in the model was set at 0.05 and at 0.1 to be removed. The variables with significant statistical differences between converters and non-converters to $\mathrm{AD}$ in T-test or Pearson's Chi-square analysis were the covariates in the Cox regression model. All statistical analyses were performed using SPSS v14.0 for Windows (SPSS Inc., Chicago, IL) and $\alpha$ was set at $5 \%$.

\section{Results}

Table 1 shows the socio-demographic data, APOE* 4 frequency and the scores on the cognitive and neuropsychological assessments in the three groups in the baseline assessment. Patients with AD were older, less educated, had a higher frequency of APOE* 4 and worse performance on cognitive and neuropsychological batteries as compared to aMCI and controls. One-hundred and eighty-three subjects had at least one follow-up assessment (40 AD patients, $76 \mathrm{MCI}$ and 71 controls). AD patients who did not comply with longitudinal reassessments had significant lower scores on the CAMOCG $(\mathrm{p}=0.040)$ and verbal fluency animal category $(\mathrm{p}=0.002)$. Patients with MCI (amnestic and non-amnestic) who did not complete at least one follow-up assessment were significantly older $(\mathrm{p}=0.002)$, and had worse performance on the MMSE ( $p=0.001)$, and on the CAMOCG ( $p=0.001)$. No significant differences were observed in the control group according to compliance status. 
Table 1 - Socio-demographic data, APOE*4 genotype, and scores on cognitive and neuropsychological tests according to the baseline diagnosis

\begin{tabular}{|c|c|c|c|c|}
\hline & Controls & $\mathrm{aMCl}$ & $A D$ & $\mathbf{p}$ \\
\hline \multicolumn{5}{|c|}{ Socio-demographic data and $\mathrm{APOE}^{\star} 4$ frequency } \\
\hline Age, years & $67.6(5.7)$ & $70.7(6.5)$ & $74.5(6.9)$ & $<0.001$ \\
\hline Education, years & $13.1(5.5)$ & $9.1(4.9)$ & $7.1(5.1)$ & $<0.001$ \\
\hline gender (W/M) & $69 / 19$ & $74 / 23$ & $51 / 22$ & 0.400 \\
\hline APOE*4 (\%) & $60 \%$ & $30 \%$ & $19 \%$ & $<0.001$ \\
\hline Age, years & $67.6(5.7)$ & $70.7(6.5)$ & $74.5(6.9)$ & $<0.001$ \\
\hline \multicolumn{5}{|c|}{ Cognitive tests and clinical scales (Hachinski and Hamilton Depression Scale - 21 item) } \\
\hline CAMCOG & $96.5(5.0)$ & $87.2(8.4)$ & $60.2(17.8)$ & $<0.001$ \\
\hline MMSE & $28.4(1.8)$ & $26.6(2.4)$ & $18.1(5.2)$ & $<0.001$ \\
\hline CDT & $8.9(1.8)$ & $7.8(1.9)$ & $5.0(2.8)$ & $<0.001$ \\
\hline VF animal & $19.6(4.3)$ & $14.7(5.1)$ & $9.7(5.1)$ & $<0.001$ \\
\hline Hachinski & $1.1(1.8)$ & $1.5(1.7)$ & $2.5(2.2)$ & $<0.001$ \\
\hline HAM-D & $1.9(3.3)$ & $2.9(3.9)$ & $2.3(3.2)$ & 0.200 \\
\hline \multicolumn{5}{|c|}{ Neuropsychological tests } \\
\hline RMBT screening & $10.2(1.5)$ & $7.5(2.1)$ & $2.6(2.9)$ & $<0.001$ \\
\hline RBMT profile & $21.7(2.2)$ & $17.3(3.7)$ & $6.9(6.0)$ & $<0.001$ \\
\hline FOME total & $43.8(3.4)$ & $39.4(6.4)$ & $20.3(11.5)$ & $<0.001$ \\
\hline FOME delayed recall & $9.4(0.9)$ & $8.5(1.5)$ & $3.7(2.9)$ & $<0.001$ \\
\hline VF fruits & $14.6(3.5)$ & $12.1(3.2)$ & $9.1(3.1)$ & $<0.001$ \\
\hline SKT total & $2.5(2.8)$ & $4.7(3.6)$ & $12.3(4.9)$ & $<0.001$ \\
\hline Trail A (s) & $49.3(17) 4$. & $79.6(42.9)$ & $127.7(58.5)$ & $<0.001$ \\
\hline Trail B (s) & $109.8(72.3)$ & $174.0(65.9)$ & $252.2(85.5)$ & $<0.001$ \\
\hline
\end{tabular}

Results are presented as means and standard deviations (SD); aMCl: Amnestic Mild Cognitive Impairment; AD: Alzheimer'sDisease. MMSE: Mini-Mental State Examination; CAMCOG Cambridge Cognitive Test; AMT: Abbreviated Mental Test; CDT: Clock Drawing Test; IQCODE: Informant Questionnaire of Cognitive Disorder of the Elderly; HIS: Hachinski Isquemic Score; HAM-D 21: Hamilton Depression Scale 21 items. BMT: Rivermead Behavioral Memory Test; FOME: Fuld Object-Memory Evaluation; SKT: Short Cognitive Test.

Sixteen subjects progressed to $\mathrm{AD}$ (3 in the control group and 13 in the MCI group) upon follow-up (mean follow-up of $38.8 \pm 17.7$ months). Patients with the baseline diagnosis of amnestic MCI had a significantly increased risk for progression to $\mathrm{AD}$ (odds ratio $=4.5,95 \%$ confidence interval of 1.3-13.6, $\mathrm{p}=0.010$ ). The annualized progression rate to $\mathrm{AD}$ was $6 \%$ in the $\mathrm{MCI}$ group, and $1 \%$ in the control group. Figure 1 shows the survival graph of $\mathrm{MCI}$ and controls. MCI subjects who progressed to $\mathrm{AD}$ were older, had higher frequency of $\mathrm{APOE}^{*} 4$, and worse baseline scores on measures of memory and verbal fluency (Table 2). The variables age, gender, APOE*4, and RBMT (screening and profile) scores, FOME (total and delay) scores, the verbal fluency fruit category and the SKT scores were covariates in the Cox regression analysis model. This analysis showed that older age $[\exp (\beta)=1.11$, S.E. $(\beta)=0.7$, Wald $=4.2, p=0.040]$, the presence of $\mathrm{APOE}^{*} 4$ allele $[\exp (\beta)=16.44$, S.E. $(\beta)=1.01$, Wald $=7.4$, $\mathrm{p}=0.006]$ and worse RBMT screening scores $[\exp (\beta)=0.78$, S.E. $(\beta)=0.1$, Wald $=5.3, p=0.020]$ were the best predictors of progression to $\mathrm{AD}$ in the patients with MCI.

In the sub sample of patients with aMCI who had CSF samples available for biomarker analysis $(n=45), 10$ progressed to $A D$ upon follow-up (MCI-AD) and 35 remained as MCI (non-converters, MCI-NC). These subjects had lower $\beta$-amyloid ${ }_{42}$ protein (MCI-AD, $319.1 \mathrm{pg} / \mathrm{mL}$ vs. MCI-NC, 443.5pg/mL, $\mathrm{t}=2.32$, $\mathrm{p}=0.020$ ), higher phospho-Tau protein (MCI-AD, $92.7 \mathrm{pg} / \mathrm{mL}$ vs. MCI-NC, $56.8 \mathrm{pg} /$ $\mathrm{mL}, \mathrm{t}=-2.7, \mathrm{p}=0.010)$ and higher total Tau (MCI-AD, 141.0pg/ $\mathrm{mL}$ vs. $\mathrm{MCI}-\mathrm{NC}, 92.3 \mathrm{pg} / \mathrm{mL}, \mathrm{t}=-2.25, \mathrm{t}=0.030)$.

\section{Discussion}

This is the first study to ascertain, in a clinical Brazilian elderly cohort, the risk of conversion from MCI to AD and its underlying cognitive and biological predictors. We show that the cross-sectional diagnosis of amnestic MCI confers a higher risk of progression to $\mathrm{AD}$ as compared to the ascertainment of unimpaired cognition. Older age, worse baseline memory function and the presence of the APOE* 4 allele are the best predictors of progression to $\mathrm{AD}$ in patients with amnestic MCI. We further show that patients with MCI who convert to AD (MCI-AD), as compared to non-converters (MCI-NC), have a CSF biomarker signature that resembles the one found in $\mathrm{AD}$ patients (i.e. low $\beta$-amyloid ${ }_{42}$, high total Tau and high phospho-Tau). The present findings are in agreement with those from previous studies carried out in other countries and settings. ${ }^{31}$ Although it was based on a clinical cohort, we believe that the present evidence will add to the existing knowledge on the risk of AD in the Brazil, which has been accumulated mostly from epidemiological studies in this country.

The annualized rate of progression to $\mathrm{AD}$ in our study (6\%) was lower than the original estimate by Petersen et al. ${ }^{28}$ (10 to $15 \%$ per year), but it is in agreement with more recent studies suggesting that the former rates may have been overestimated, given the smaller numbers provided by recent longitudinal observations. ${ }^{32}$ Attrition resulted in the unavailability to reassess 21 patients with amnestic MCI. Because these subjects were older and had worse baseline cognitive performance, making 
Table 2 - Socio-demographic data, APOE*4 genotype, and scores on cognitive and neuropsychological tests according to the evolutive diagnosis

\begin{tabular}{|c|c|c|c|}
\hline & $\mathrm{MCl}-\mathrm{AD}$ & $\mathrm{MCl}-\mathrm{NC}$ & $\mathbf{p}$ \\
\hline \multicolumn{4}{|c|}{ Socio-demographic data and $\mathrm{APOE}^{*} 4$ frequency } \\
\hline Age, years $(S D)$ & $75.8(5.8)$ & $68.7(5.6)$ & $<0.001$ \\
\hline Education, years (SD) & $9.8(6.2)$ & $9.2(4.8)$ & 0.700 \\
\hline gender $(\mathrm{W} / \mathrm{M})$ & $5 / 8$ & $53 / 10$ & $<0.001$ \\
\hline $\mathrm{APOE}^{*} 4(\%)$ & $70 \%$ & $30 \%$ & 0.006 \\
\hline \multicolumn{4}{|c|}{$\begin{array}{l}\text { Cognitive tests and clinical scales (Hachinski and Hamilton } \\
\text { Depression Scale }-21 \text { item) }\end{array}$} \\
\hline CAMCOG & $87.9(6.4)$ & $88.5(8.5)$ & 0.800 \\
\hline MMSE & $27.1(2.6)$ & $27.1(2.1)$ & 1.000 \\
\hline CDT & $7.4(2.2)$ & $7.9(1.9)$ & 0.400 \\
\hline VF animal & $13.7(4.2)$ & $15.5(5.6)$ & 0.300 \\
\hline Hachinski & $1.2(1.0)$ & $1.7(1.9)$ & 0.400 \\
\hline HAM-D & $3.2(2.8)$ & $2.8(3.8)$ & 0.800 \\
\hline \multicolumn{4}{|c|}{ Neuropsychological tests } \\
\hline RMBT screening & $5.8(2.3)$ & $7.8(1.9)$ & 0.004 \\
\hline RBMT profile & $15.5(4.4)$ & $17.7(3.5)$ & 0.100 \\
\hline FOME total & $35.0(8.9)$ & $40.2(6.0)$ & 0.010 \\
\hline FOME delayed recall & $7.4(1.8)$ & $8.6(1.4)$ & 0.010 \\
\hline VF fruits & $9.8(2.6)$ & $12.8(3.2)$ & 0.005 \\
\hline SKT total & $6.7(4.4)$ & $4.2(3.3)$ & 0.030 \\
\hline Trail A (s) & $82.8(51.0)$ & $74.0(39.1)$ & 0.500 \\
\hline Trail B (s) & $157(50.9)$ & $169.8(64.2)$ & 0.600 \\
\hline
\end{tabular}

Results are presented as means and standard deviations (SD); $\mathrm{MCl}-\mathrm{AD}$ : $\mathrm{MCl}$ patients who progressed to $A D ; \mathrm{MCl}-\mathrm{NC}$ : $\mathrm{MCl}$ patients who did not progress to AD. MMSE: Mini-Mental State Examination; CAMCOG Cambridge Cognitive Test; AMT: Abbreviated Mental Test; CDT: Clock Drawing Test; IQCODE: Informant Questionnaire of Cognitive Disorder of the Elderly; HIS: Hachinski Isquemic Score; HAM-D 21: Hamilton Depression Scale 21 items. BMT: Rivermead Behavioral Memory Test; FOME: Fuld Object-Memory Evaluation; SKT: Short Cognitive Test our estimate conservative, the annualized progression rate to $\mathrm{AD}$ of $6 \%$ may have been underestimated in this sample. Anyhow, our data are in agreement with a recent metaanalysis on the risk of progression from MCI to AD. ${ }^{33}$ The discrepancy between different studies may be due to several reasons, namely: distinct diagnostic criteria for MCI and/or comprehensiveness of assessment schedules across different studies; lack of gold standards for cognitive evaluation; ${ }^{7,34}$ nonobjective definition of functional impairment and subsequent inaccuracy of the dementia threshold; ${ }^{35}$ recruitment of subjects with MCI at different stages of cognitive impairment; ${ }^{32,36}$ and finally the diagnostic instability of the MCI concept, yielding longitudinal outcomes that are not necessarily related with baseline diagnoses. ${ }^{8,36}$

In view of these limitations, biomarker technologies have been developed in the past years in an attempt to improve the specificity of the clinical diagnosis of MCI. The rationale is to depict the subjects at higher risk of evolving to $\mathrm{AD}$ from larger samples. ${ }^{37}$ In the present study, we found that MCI subjects displaying an abnormal AD-like pattern of CSF biomarkers (i.e., lower $A \beta_{42}$ and higher total- and phospho-TAU) had an increased risk of progressing to dementia. Other techniques with promising diagnostic support are longitudinal measurements of wholebrain and/or hippocampal atrophy with structural MRI, cerebral blood flow with SPECT, and cerebral metabolism or amyloid imaging with PET scans. ${ }^{16,18,38}$ Additionally, the combination of these diagnostic strategies seems to increase the predictive power to identify $\mathrm{AD}$ patients at the prodromal stages of the disease. ${ }^{39}$ According to a recent task-force that proposed the revised

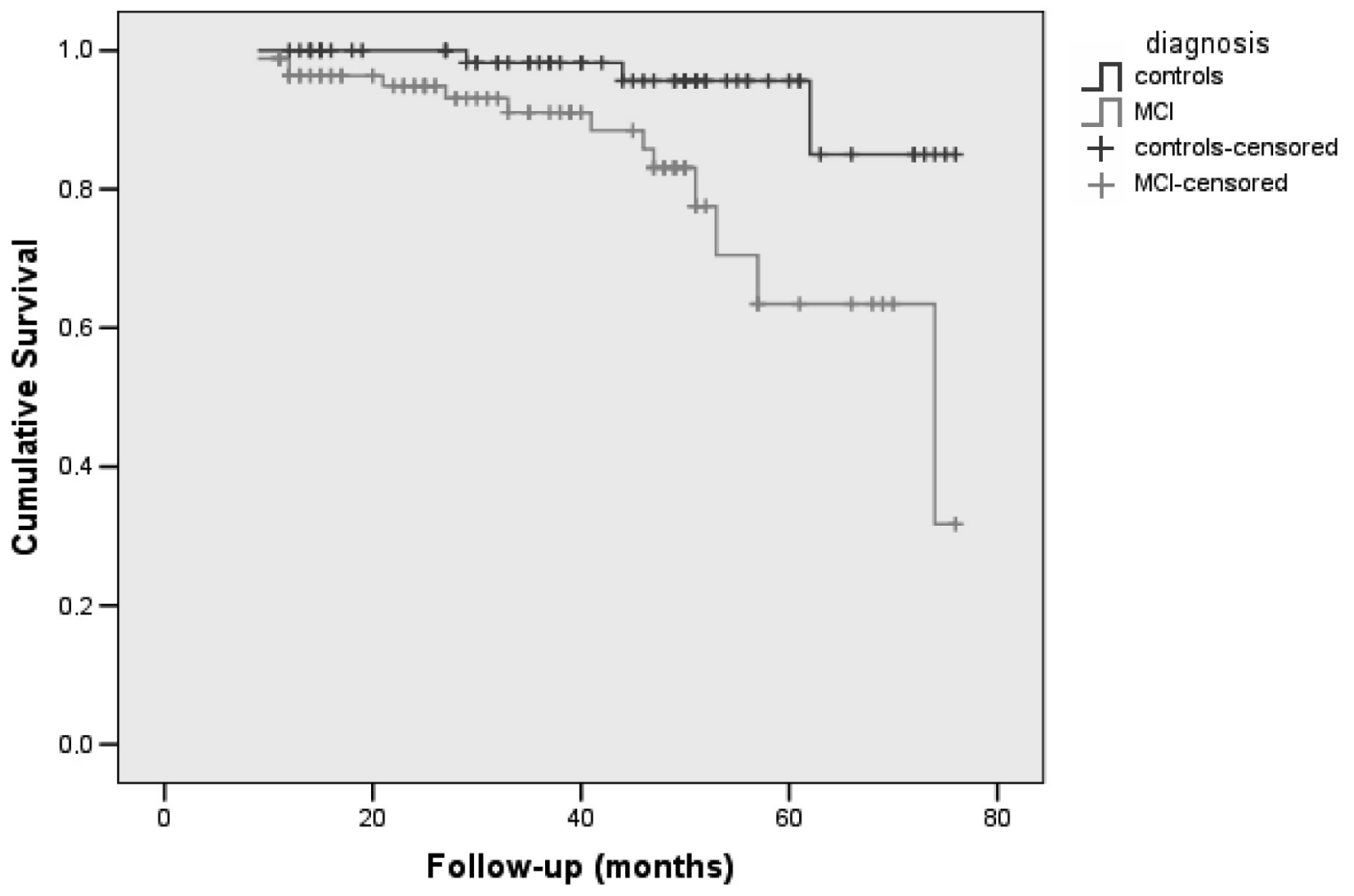

Figure 1 - Survival analysis of the conversion from amnestic $\mathrm{MCI}$ to $\mathrm{AD}$. 
NINCDS-ADRDA diagnostic criteria for research, ${ }^{40}$ the presence of AD-compatible pathological findings, as indicated by one or more of these biomarkers, endorses the diagnosis of incipient (pre-dementia) AD given the clinical characterization of episodic memory impairment.

In conclusion, despite the increased risk of $\mathrm{AD}$, the cross-sectional (clinical) diagnosis of amnestic MCI is by no means a synonym of prodromal $\mathrm{AD}$. On clinical grounds, the combination of cognitive tests may not guarantee adequate diagnostic accuracy. Longitudinal reassessment of MCI patients with neuropsychological measurements is probably the best strategy, provided these tests are sensitive to the pathological changes that occur along the MCI-AD continuum. Advanced diagnostic methods, including imaging and CSF biomarkers, may add diagnostic accuracy to determine the actual risk of $\mathrm{AD}$ in such samples of patients.

\section{Disclosures}

\begin{tabular}{|c|c|c|c|c|c|c|c|}
\hline $\begin{array}{l}\text { Writing group } \\
\text { member }\end{array}$ & Employment & Research grant $^{1}$ & $\begin{array}{l}\text { Other research grant } \\
\text { or medical continuous } \\
\text { education }\end{array}$ & $\begin{array}{l}\text { Speaker's } \\
\text { honoraria }\end{array}$ & $\begin{array}{l}\text { Ownership } \\
\text { interest }\end{array}$ & $\begin{array}{l}\text { Consultant/ } \\
\text { Advisory } \\
\text { board }\end{array}$ & Other $^{3}$ \\
\hline \multirow[t]{2}{*}{$\begin{array}{l}\text { Orestes V. } \\
\text { Forlenza }\end{array}$} & \multirow[t]{2}{*}{ IPq-FMUSP } & $\begin{array}{c}\text { FAPESP grant } \\
02 / 12633-7^{* *}\end{array}$ & \multirow[t]{2}{*}{-} & $\begin{array}{l}\text { Janssen- } \\
\text { Cilag** }\end{array}$ & \multirow[t]{2}{*}{-} & $\begin{array}{l}\text { Janssen- } \\
\text { Cilag** }\end{array}$ & \multirow[t]{2}{*}{-} \\
\hline & & $\begin{array}{c}\text { CNPq grant } \\
554535 / 2005-0^{* *}\end{array}$ & & Novarti ${ }^{* *}$ & & Novarti** & \\
\hline Breno S. Diniz & IPq-FMUSP & - & CAPES, Ph.D program** & - & - & - & - \\
\hline Leda L. Talib & IPq-FMUSP & - & - & - & - & - & - \\
\hline $\begin{array}{l}\text { Marcia } \\
\text { Radanovic }\end{array}$ & IPq-FMUSP & - & - & - & - & - & - \\
\hline $\begin{array}{l}\text { Monica S. } \\
\text { Yassuda }\end{array}$ & $\begin{array}{l}\text { IPq-FMUSP } \\
\text { EACH-USP }\end{array}$ & - & - & - & - & - & - \\
\hline Elida B. Ojopi & $\mathrm{IPq}, \mathrm{FMUSP}$ & $\begin{array}{l}\text { FAPESP grant } \\
02 / 12633-7^{\star *} \\
\text { CNPq grant } \\
554535 / 2005-0^{\star *}\end{array}$ & - & - & - & - & - \\
\hline $\begin{array}{l}\text { Wagner F. } \\
\text { Gattaz }\end{array}$ & IPq, FMUSP & $\begin{array}{l}\text { FAPESP grant } \\
02 / 12633-7^{* *} \\
\text { CNPq grant } \\
554535 / 2005-0^{*} \\
\text { ABADHS**}\end{array}$ & $\begin{array}{c}\text { AstraZeneca** } \\
\text { Bristol Myers-Squibb** } \\
\text { Eli Lilly** } \\
\text { Janssen-Cilag** }\end{array}$ & $\begin{array}{l}\text { AstraZeneca** } \\
\text { Bristol Myers- } \\
\text { Squibb** } \\
\text { Eli Lilly**} \\
\text { Janssen- } \\
\text { Cilag }\end{array}$ & - & $\begin{array}{l}\text { AstraZeneca** } \\
\text { Bristol Myers- } \\
\text { Squibb** } \\
\text { Eli Lilly** } \\
\text { Janssen- } \\
\text { Cilag }^{\star *}\end{array}$ & - \\
\hline $\begin{array}{l}\text { * Modest } \\
\text { ** Significant } \\
\text { *** Significant. Am } \\
\text { Note: IPq-FMUSP } \\
\text { Humanidades da } \\
\text { Nacional de Deser } \\
\text { For more informati }\end{array}$ & $\begin{array}{l}\text { ts given to the } \\
\text { istituto de Psiq }\end{array}$ & $\begin{array}{l}\text { hor's institution or } \\
\text { tria da Faculdade } \\
\text { Paulo; FAPESP } \\
\text { e Tecnológico; } A D \\
\text { r Authors. }\end{array}$ & $\begin{array}{l}\text { colleague for research ir } \\
\text { Medicina da Universidade } \\
\text { Fundação de Amparo à } \\
\text { HS = Associação Benefic }\end{array}$ & $\begin{array}{l}\text { hich the author } \\
\text { São Paulo; EA } \\
\text { squisa do Esta } \\
\text { te Alzira Denis }\end{array}$ & $\begin{array}{l}\text { as participat } \\
H-U S P=E \\
\text { o de São } P \\
\text { Hertzog da }\end{array}$ & $\begin{array}{l}\text { not directly to } \\
\text { la de Artes, Cie } \\
\text { a. CNPq = Co }\end{array}$ & $\begin{array}{l}\text { autho } \\
\text { siase } \\
\text { elho }\end{array}$ \\
\hline
\end{tabular}

References

1. Winblad B, Palmer K, Kivipelto M, Jelic V, Fratiglioni L, Wahlund LO, Nordberg A, Bäckman L, Albert M, Almkvist O, Arai H, Basun H, Blennow K, de Leon M, DeCarli C, Erkinjuntti T, Giacobini E, Graff C, Hardy J, Jack C, Jorm A, Ritchie K, van Duijn C, Visser P, Petersen RC. Mild cognitive impairment-beyond controversies, towards a consensus: report of the International Working Group on Mild Cognitive Impairment. J Intern Med. 2004;256(3):240-6.

2. Bruscoli M, Lovestone $S$. Is MCI really just early dementia? A systematic review of conversion studies. Int Psychogeriatr. 2004;16(2):128-40.

3. Hototian SR, Lopes MA, Azevedo D, Tatsch M, Bazzarella MC, Bustamante SEZ, Litvoc J, Bottino CMC. Prevalence of Cognitive and Functional Impairment in a Community Sample from São Paulo, Brazil. Dement Geriatr Cogn Disord. 2008;25(2):135-43.

4. Chaves ML, Camozzato AL, Godinho C, Piazenski I, Kaye J. Incidence of Mild Cognitive Impairment and Alzheimer Disease in Southern Brazil. J Geriatr Psychiatry Neurol. 2009;22(3):181-7.

5. Diniz BS, Yassuda MS, Nunes PV, Radanovic M, Forlenza OV. Mini-mental State Examination performance in mild cognitive impairment subtypes. Int Psychogeriatr. 2007;19(4):647-56.
6. Diniz BS, Nunes PV, Yassuda MS, Pereira FS, Flaks MK, Viola LF, Radanovic M, Abreu ID, Borelli DT, Gattaz WF, Forlenza OV. Mild cognitive impairment: cognitive screening or neuropsychological assessment? Rev Bras Psiquiatr. 2008;30(4):316-21.

7. Forlenza OV, Chiu E. Mild cognitive impairment: a concept ready to move on? Curr Opin Psychiatry. 2008;21(6):529-32.

8. Diniz BS, Nunes PV, Yassuda MS, Forlenza OV. Diagnosis of mild cognitive impairment revisited after one year: preliminary results of a prospective study. Dement Geriatr Cogn Disord. 2009;27(3):224-31.

9. Busse A, Hensel A, Gühne U, Angermeyer MC, Riedel-Heller SG. Mild cognitive impairment: long-term course of four clinical subtypes. Neurology. 2006;67(12):2176-85.

10. Diniz BS, Pinto Jr. JA, Gonzaga ML, Guimarães FM, Gattaz WF, Forlenza OV.To treat or not to treat? A meta-analysis of the use of cholinesterase inhibitors in mild cognitive impairment for delaying progression to Alzheimer's disease. Eur Arch Psychiatry Clin Neurosci. 2009;259(4):248-56.

11. Nunes PV, Forlenza OV, Gattaz WF. Lithium and neuroprotection: new potential uses in psychiatry. Rev Psiq Clin. 2007;34(6):294-5.

12. Tyas SL, Salazar JC, Snowdon DA, Desrosiers MF, Riley KP, Mendiondo MS, Kryscio RJ. Transitions to Mild Cognitive Impairments, 
Dementia, and Death: Findings from the Nun Study. Am J Epidemiol. 2007;165(11):1231-8

13. Rozzini L, Chilovi BV, Conti M, Bertoletti E, Delrio I, Trabucchi M, Padovani A. Conversion of amnestic Mild Cognitive Impairment to Dementia of Alzheimer type is independent to memory deterioration. Int J Geriatr Psychiatry. 2007(12);22:1217-22.

14. Tschanz JT, Welsh-Bohmer KA, Lyketsos CG, Corcoran C, Green RC, Hayden K, Norton MC, Zandi PP, Toone L, West NA, Breitner JC; Cache County Investigators. Conversion to dementia from mild cognitive disorder: The Cache County Study. Neurology. 2006;67(2):229-34.

15. Hansson O, Zetterberg H, Buchhave P, Londos E, Blennow K, Minthon L. Association between CSF biomarkers and incipient Alzheimer's disease in patients with mild cognitive impairment: a follow-up study. Lancet Neurol. 2006;5(3):228-34.

16. Busatto GF, Diniz, BS, Zanetti, MV. Voxel-based morphometry in Alzheimer's disease. Expert Rev Neurother. 2008;8(11):1691-702.

17. Jack Jr. CR, Shiung MM, Weigand SD, O’Brien PC, Gunter JL, Boeve BF, Knopman DS, Smith GE, Ivnik RJ, Tangalos EG, Petersen RC. Brain atrophy rates predict subsequent clinical conversion in normal elderly and amnestic MCI. Neurology. 2005;65(8):1227-31.

18. Hirao K, Ohnishi T, Hirata Y, Yamashita F, Mori T, Moriguchi Y, Matsuda H, NemotoK, Imabayashi E, Yamada M, Iwamoto T, Arima K, Asada T. The prediction of rapid conversion to Alzheimer's disease in mild cognitive impairment using regional cerebral blood flow SPECT. NeuroImage. 2005;28(4):1014-21.

19. Jagust W, Gitcho A, Sun F, Kuczynski B, Mungas D, Haan M. Brain imaging evidence of preclinical Alzheimer's disease in normal aging. Ann Neurol. 2006;59(4):673-81.

20. Roth M, Tym E, Mountjoy CQ, Huppert FA, Hendrie H, Verma S, Goddard R. CAMDEX: a standardized instrument for the diagnosis of mental disorders in the elderly with special reference to early detection of dementia. Br J Psychiatry. 1986;149:698-709.

21. Bottino CM, Almeida OP, Tamai S, Forlenza OV, Scalco MZ, Carvalho IAM. Entrevista estruturada para diagnóstico de transtornos mentais em idosos. São Paulo: PROTER, Instituto de Psiquiatria do Hospital das Clínicas da Faculdade de Medicina da USP; 1999.

22. Hamilton M. A rating scale for depression. J Neurol Neurosurg Psychiatry. 1960;23:56-62.

23. Wilson B, Cockburn J, Baddeley AD. Rivermead behavioural memory test. Suffolk, England: Thames Valley Test Company; 1985.

24. Fuld P. Guaranteed stimulus processing in the evaluation of memory and learning. Cortex. 1980;16(2):255-71.

25. Flaks MK, Yassuda MS, Regina AC, Cid CG, Camargo CH, Gattaz WF, Forlenza OV. The Short Test (SKT). A cognitive performance a preliminary study in of its psychometric properties in Brazil. Int Psychogeriatr. 2006;18(1):121-33.

26. Jorm AF, Jacomb PA. The Informant Questionnaire on Cognitive Decline in the Elderly (IQCODE): socio-demographic correlates, reliability, validity and some norms. Psychol Med. 1989;19(4): 1015-22.

27. McKhann G, Drachman D, Folstein M, Katzman R, Price D, Stadlan EM. Clinical diagnosis of Alzheimer disease: report of NINCDSADRDA Work Group under the auspices of Department of Health and Human Service Task Force on Alzheimer's Disease. Neurology. 1984;34(7):939-44.

28. Petersen RC, Smith GE, Waring SC, Ivnik RJ, Tangalos EG, Kokmen E. Mild cognitive impairment: clinical characterization and outcome. Arch Neurol. 1999;56(3):303-8.

29. Yassuda MS, Diniz BS, Flaks MK, Viola LF, Pereira FS, Nunes PV, Forlenza OV. Neuropsychological profile of Brazilian older adults with heterogeneous educational backgrounds. Arch Clin Neuropsychol. 2009;24(1):71-9.

30. Livak KJ. Allelic discrimination using fluorogenic probes and the 59 nuclease assay. Genet Anal. 1999;14(5-6):143-9.

31. Diniz BS, Pinto Júnior JA, Forlenza OV. Do CSF total tau, phosphorylated tau, and beta-amyloid 42 help to predict progression of mild cognitive impairment to Alzheimer's disease? A systematic review and meta-analysis of the literature. World J Biol Psychiatry. 2008;9(3):172-82.

32. Feldman HH, Ferris S, Winblad B, Sfikas N, Mancione L, He Y, Tekin S, Burns A, Cummings J, del Ser T, Inzitari D, Orgogozo JM, Sauer H, Scheltens P, Scarpini E, Herrmann N, Farlow M, Potkin S, Charles HC, Fox NC, Lane R. Effect of rivastigmine on delay to diagnosis of
Alzheimer's disease from mild cognitive impairment: the InDDEx study. Lancet Neurol. 2007;6(6):501-12.

33. Mitchell AJ, Shiri-Feshki M. Rate of progression of mild cognitive impairment to dementia - meta-analysis of 41 robust inception cohort studies. Acta Psychiatr Scand. 2009;119(4):252-65.

34. Petersen RC. MCI treatment trials: failure or not? Lancet Neurol. 2007;6(6):473-5. 35. Pereira FS, Yassuda MS, Oliveira AM, Forlenza OV. Executive dysfunction correlates with impaired functional status in older adults with varying degrees of cognitive impairment. Int Psychogeriatr. 2008;20(6): 1104-15.

36. Visser PJ, Sheltens P, Verhey FRJ. Do MCI criteria in drug trials accurately identify subjects with pre-dementia Alzheimer's disease? J Neurol Neurosurg Psychiatry. 2005;76(10):1348-54.

37. Engelborghs S, De Vreese K, Van de Casteele T, Vanderstichele H, Van Everbroeck B, Cras P, Martin J-J, Vanmechelen E, De Deyn PP. Diagnostic performance of a CSF-biomarker panel in autopsy-confirmed dementia. Neurobiol Aging. 2008:29(8):1143-59.

38. Anchisi D, Borroni B, Franceschi M, Kerrouche N, Kalbe E, BeuthienBeumann B, Cappa S, Lenz O, Ludecke S, Marcone A, Mielke R, Ortelli P, Padovani A, Pelati O, Pupi A, Scarpini E, Weisenbach S, Herholz K, Salmon E, Holthoff V, Sorbi S, Fazio F, Perani D. Heterogeneity of Brain Glucose Metabolism in Mild Cognitive Impairment and Clinical Progression to Alzheimer Disease. Arch Neurol. 2005;62(11):1728-33.

39. Hansson O, Buchhave P, Zetterberg H, Blennow K, Minthon L, Warkentin $S$. Combined rCBF and CSF biomarkers predict progression from mild cognitive impairment to Alzheimer's disease. Neurobiol Aging. 2009;30(2):165-73.

40. Dubois B, Feldman HH, Jacova C, Dekosky ST, Barberger-Gateau P, Cummings J, Delacourte A, Galasko D, Gauthier S, Jicha G, Meguro, O'brien J, Pasquier F, Robert P, Rossor M, Salloway S, Stern Y, Visser PJ, Scheltens P. Research criteria for the diagnosis of Alzheimer's disease: revising the NINCDS-ADRDA criteria. Lancet Neurol. 2007;6(8):734-46. 